Astronomy
International array
project looks set to
sign up Japan
$p 627$

\title{
Medicine Nobel goes to pioneer of protein guidance mechanisms
}

\section{London}

This year's Nobel Prize for Physiology or Medicine has been awarded to Günter Blobel, of the Rockefeller University in New York, for his discovery that proteins are manufactured with in-built address labels that guide them to their destinations in the cell.

Cells contain compartments in which proteins perform distinct tasks. For example, DNA is transcribed in the nucleus, energy is generated in mitochondria, and the export of proteins out of the cell involves the endoplasmic reticulum.

The boundaries of these compartments are formed by lipid membranes that are largely impermeable to proteins. Most proteins, however, are made in the fluid surrounding the compartments, the cytoplasm. This raises the questions: How do these proteins know where to go? And how do they make their way through the lipid membrane?

Blobel found answers to both questions. Born in Germany in 1936, he took his MD at the University of Tübingen and his $\mathrm{PhD}$ at the University of Wisconin in Madison. He joined the laboratory of George Palade - a Nobel laureate himself - at Rockefeller University as a postdoctoral fellow in 1967.

In 1971, with his then collaborator David Sabatini, Blobel suggested that secreted proteins contain intrinsic signals that deliver them to and across the endoplasmic reticulum membrane.

"These targeting signals are genetically encoded. They are built into the amino-acid sequences of the protein, and are an integral part of its structure. It's a brilliant and imaginative concept," says Gideon Dreyfuss, of the Howard Hughes Medical Institute at the University of Pennsylvania, Philadelphia. "It turned out to be correct, and spawned much of today's research on intracellular transport.'

Blobel wrote in an article in Current Contents in 1985 that the "first experimental landmark" supporting his theory was the finding by César Milstein and his colleagues of a transient amino-acid sequence at the end of a protein that was secreted from the cell.

Based on this finding and their own evidence, Blobel and Bernard Dobberstein formulated in 1975 their 'signal hypothesis'.

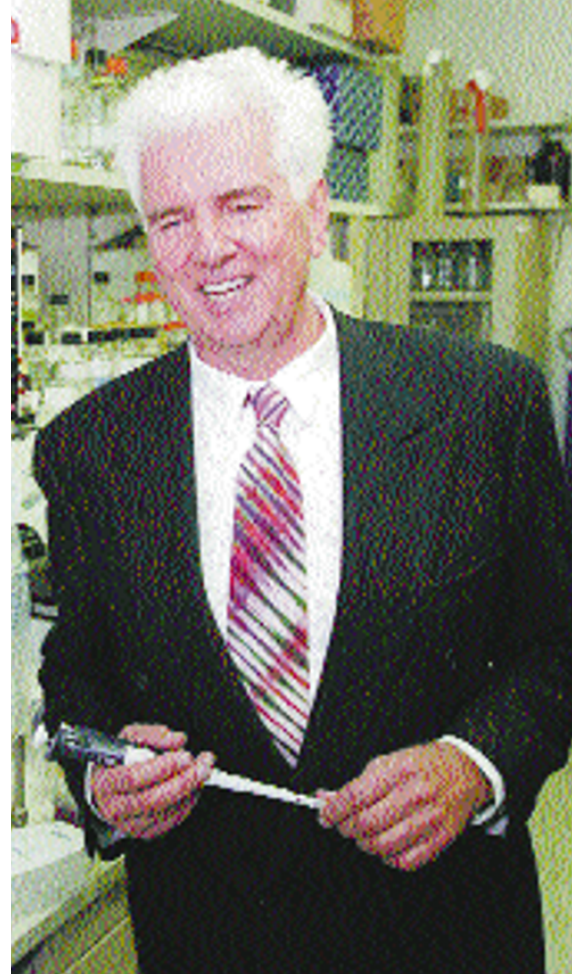

Blobel: 'trailblazer' in molecular cell biology.

This predicted — in breathtaking detail how newly formed proteins were targeted to the endoplasmic reticulum and entered it through a channel in the membrane. Sabatani, now at New York University, says: "One of my greatest satisfactions was to see some of those beautiful ideas substantiated by elegant and rigorous experiments carried out in Günter's laboratory."

William Wickner of Dartmouth Medical School in Hanover, New Hampshire, says: "Blobel predicted that there would be specific sorting receptors that recognized the signals. He went on to discover one such recognition system, the signal recognition particle and its membrane receptor, and to find that this system can coordinate protein synthesis and translocation. This work set the standard for studies in the fields of translocation and protein trafficking."

Since then, it has been shown that Blobel's signal hypothesis was correct and universal: different organelles import proteins in a similar manner, and the process is essentially identical in yeast, plant and animal cells.

Today cell biologists "take the concept of intrinsic signals for granted", says Harris Bernstein of the US National Institutes of Health. "It's so largely engrained that people forget about where it came from." But, he adds, "it was revolutionary in its day".

The Nobel prize did not come as a surprise to Blobel's peers. Most consider it well deserved and long overdue (Blobel was awarded the Lasker Prize in 1993). "For 20 years Günter Blobel has been the trailblazer and pace setter in a major field in cellular and molecular biology," says a delighted Palade. Angus Lamond of the University of Dundee, Scotland, describes Blobel as one of the key figures who has transformed 'cell biology' into 'molecular cell biology'.

Palade adds that equally worthy of high recognition is Blobel's success in training an impressive group of young investigators. "Among them are the new leaders, or the promising future leaders of the field," Palade says. "This is the beginning of a dynasty." This group includes Dobberstein, who currently works at the University of Heidelberg, Larry Gerace of the Scripps Research Institute in La Jolla, California, and Vishwanath Lingappa and Peter Walter, both at the University of California in San Francisco.

Lingappa fondly recalls the night when Blobel returned to the lab after a smart party to finish his experiments - still wearing his tuxedo. "Such was his complete focus on the problem, the passion and his commitment to solving it."

Walter puts it slightly differently: "He has never shied away from controversy, and has aided the field by adhering to clear and testable hypotheses. Often he appeared dogmatic, yet he has always been [open to being convinced] by clean and unrefutable data. I couldn't have wished for a better mentor when I was a graduate student in his lab."

Blobel reportedly plans to donate part of his $\$ 960,000$ prize money towards the rebuilding of the Frauenkirche cathedral, which was destroyed in the bombing of Dresden in 1945.
Marie-Thérèse Heemels 